\title{
THE MUHAMMADIYAH CRITICISM AGAINST MAWLID TRADITION OVER CENTURIES
}

\author{
Muhammad As'ad | \\ Radboud University, Nijmegen - Netherland and Hasyim Asy'ari University, \\ Jombang - Indonesia | muhammad.asad@tebuireng.net
}

\begin{abstract}
This article seeks to find the change of the stand of the Muhammadiyah on the practice of the mawlid celebration. It will observe through the publication of the Muhammadiyah especially its monthly magazine of Suara Muhammadiyah. In addition, this paper will also use some opinions of the early scholars of the Muhammadiyah in the same topic. To analyze the change, this paper will use the proposed analysis of Talal Asad of discursive tradition. In the conclusion, the paper determines that the change of the stand of the Muhammadiyah on the mawlid is influenced by several factors especially the dominant political and power relations in specific time and place which determine the discourse of the mawlid criticism of the Muhammadiyah.
\end{abstract}

Keywords: Muhammadiyah, the mawlid tradition, the mawlid criticisim

\section{Introduction}

This article focuses on the discourse of mawlid criticism that is disseminated by the reformist organization of Muhammadiyah. It will particularly answer the question: what is the Muhammadiyah's opinion on the mawlid celebration in the $20^{\text {th }}$ century and how this discourse changes in the $21^{\text {st }}$ century. To observe that change, I will analyze the question and answer column (QA) of the journal of Suara Muhammadiyah (the Voice of Muhammadiyah/SM). Before answering those questions, this paper will first discern the history of mawlid criticism the $20^{\text {th }}$ century Indonesia, who was the first person that voiced the criticism and what his/her relation with Muhammadiyah.

To analyze the discourse of Muhammadiyah on the mawlid criticism, I will use the approach of discursive tradition that is 
proposed by Talal Asad (1986). According to Asad, if someone would like to study one tradition/ritual in Islam: "one should begin, as Muslims do, from the concept of discursive tradition that includes and relates itself to the founding texts of the Qur'an and the hadith'." Asad explains further this concept by elucidating the definition of tradition. According to him:

"A tradition consists essentially of discourses that seek to instruct practitioners regarding the correct form and purpose of a given practice that, precisely because it is established, has a history. These discourses relate conceptually to a past (when the practice was instituted, and from which the knowledge of its point and proper performance has been transmitted) and a future (how the point of that practice can best be secured in the short or long term, or why it should be modified or abandoned), through a present (how it is linked to other practices, institutions, and social conditions). An Islamic discursive tradition is simply a tradition of Muslim discourse that addresses itself to conceptions of the Islamic past and future, with reference to a particular Islamic practice in the present". ${ }^{2}$

From his description, Talal Asad emphasizes one important element that is needed to be understood for anyone who would like to apply this approach. That element is the understanding of the definition of orthodoxy or the correct belief. For Asad, orthodoxy is not an opinion in which a tradition is perceived as right or wrong. Moreover, he explains more by stating that an orthodoxy is "a distinctive relationship - the relationship of power to truth. Wherever Muslims have the power to regulate, uphold, require, or adjust correct practices, and to condemn, exclude, undermine, or replace incorrect ones, there is the domain of orthodoxy". ${ }^{3}$

By using this approach, we can apprehend that a discourse in one Muslim society pertaining to one religious tradition in specific time and place, does not stand independently. It is influenced by other discourses, religious institution and also the social and political landscape at that particular time. Most importantly, a religious discourse is highly influenced by power relation of Muslim groups to control or denounce that religious practice. This is what is mentioned

1 Talal Asad, The Idea of an Anthropology of Islam, Occasional Papers Series (Washington D.C., 1986), p. 14.

2 Ibid., p. 14.

3 Ibid., p. 15. 
by Talal Asad as "the domain of orthodoxy." In this regard, a discourse on orthodoxy will always be opposed by other Islamic groups. What is called as orthodoxy, in Talal Asad's point of view, is a dominant discourse in specific time and place.

This paper consists of four parts. This first one will see the history of mawlid criticism and how this discourse occurred in Indonesian history. The second part is the discourse of mawlid criticism within the reformist organization of Muhammadiyah in the $20^{\text {th }}$ century. The last part will elucidate the stand of Muhammadiyah on mawlid in the $21^{\text {st }}$ century. This paper will be ended with a conclusion.

\section{The Emergence of Mawlid Criticism}

Mawlid celebration is a festive that is practiced for centuries. There are several academic works that trace the history of this tradition. One work that comprehensively discusses the early years of this tradition is written by Nico Kaptein. ${ }^{4}$ In that book, Kaptein concludes that the mawlid was firstly celebrated by the Shiite Fatimid caliphate in Egypt in the $11^{\text {th }}$ century. When the Fatimid dynasty fell, the mawlid was continued by the Sunnite ruler of Syria, Nur al-Din (d. 1174) with some modifications. The main change is that Nur al-Din eliminated the celebration of Shi'i figures such as Ali, Fatima, Hasan, and Husein.

After it was celebrated in Syria, the mawlid was disseminated widely in the Sunnite world in a short period. How it was spread is unknown, but Kaptein holds that it were the guests of Nur al-Din's mawlid who possibly brought and reproduced the mawlid into their hometowns. This is evident in the work of Ibnu Jubayr who mentioned that during his visit to Mecca in 1184, the Prophet's birthday was celebrated. ${ }^{5}$

Regarding the discourse of mawlid criticism, it was Taj al-Din al Fakihani (1331), an Alexandrian Maliki Jurist, who was the first generation of the 'ulama's who rejected and criticized this event. As a Maliki jurist, e issued a fatwa stating that mawlid is not authentic because it is not mentioned in the Qur'ān and hadith, and therefore, should be categorised as an innovation (bid'a). Another 'ulama' who criticize the

\footnotetext{
${ }^{4}$ Nico Kaptein, Muhammad's Birthday Festival: Early History in the Central Muslim Lands and Developement in the Muslim West until the 10th/16 Century (Leiden: EJ. Brill, 1993).

5 Nico Kaptein, "Materials for the History of the Prophet Muhammad's Birthday Celebration in Mecca.Pdf," Der Islam 2, 69 (1992): pp. 193-203.
} 
mawlid is Ibn Taymiya (1263-1328) who had the same stand as Fakihani. ${ }^{6}$

Despite some criticisms, this celebration was still perpetuated and practised in the Muslim world. In the eighteenth century, there was even a mawlid book that was written by a Shafi'i mufti of Medina, Ja'far ibn Hasan ibn 'Abd al-Karim al-Barzanji (1716-1764). This book has become one of the most popular mawlid books until today. Marion Katz argues that during the eighteenth and nineteenth century, mawlid celebrations were supported by mainstream Sunni scholars. ${ }^{7}$

Another notable criticism was expressed in the late $18^{\text {th }}$ century by Muhammad ibn 'Abd al-Wahhāb (1703-1792). He was a scholar born in Saudi Arabia and the founder of the Wahabi movement, who tried to purify Islam by eliminating all religious innovation including the mawlid. ${ }^{8}$ Yet, it seems that his influence was not strong enough to be able to cease the festival. The work of Snouck Hurgronje, which was based on his six months stay in Mecca (1884-1885), shows that mawlid was still celebrated in Mecca in the $19^{\text {th }}$ century. Based on his observation, the mawlid in Mecca was rejoiced not only in Rabi' alAwwal, the name of the month when the Prophet Muhammad was born, but also on other occasions like a boy's circumcision, wedding ceremonies and returning home from a journey. ${ }^{9}$ The marginalisation of the mawlid in Mecca (and Saudi Arabia) took place in the latetwentieth century especially after the oil-price boom of the 1970s which benefitted Saudi Arabia tremendously. With this funding, the Saudi regime was able to condemn mawlid and put the supporters of the celebration in a defensive position. ${ }^{10}$

In the early $20^{\text {th }}$ century, another critic of the mawlid emerged in Egypt along with the arrival of the movement of Islamic reformism. It was Rashid Ridha (1865-1935) who had a similar view as the Wahabi on the legal status of the mawlid celebration. He mostly dissimanated his view in his famous jounal of al manar. Nonetheless, even though he stated that the mawlid is bid'a, Ridha gave permission to someone to

\footnotetext{
6 Marion Holmes Katz, The Birth of the Prophet Mubammad; Devotional Piety in Sunni Islam (London and New York: Routledge, 2007), p. 70; p. 140.

7 Ibid., p. 169.

8 Natana J Delong-bas, Wabhabi Islam: From Revival and Reform to Global Jibad (London: Oxford University Press, 2004).

9 C. Snouck Hurgronje, Mekeka in the Latter Part of the 19th Century (Leiden: Brill, 2007).

10 Delong-bas, Wabhabi Islam: From Revival and Reform to Global Jibad.
} 
practice the mawlid if he could guarantee that the celebration did not contain negative elements such as singing, poetry recitation and a fabricated story about the Prophet. ${ }^{11}$

\section{Discourse of Mawlid Criticism in Indonesia}

How the mawlid criticism came to Indonesia? The network of Indonesian students in the Middle East is the answer for that question. This network emerged and developed in the $16^{\text {th }}$ century when many Indonesian students went to Mecca and Madinah to study Islam. ${ }^{12}$ In the 19th century, since al-Manar was published in Egypt, this network grew extensively. As it is showed by Jajat Burhanuddin, that the Southeast Asian 'Ulamä' used their network in the Middle East to gain religious authority to solve religious problems in Indonesia. ${ }^{13}$

According to several researchers, such as William Roff, 14 Azyumardi Azra ${ }^{15}$, Jajat Burhanuddin ${ }^{16}$ dan Hafiz Zakariya ${ }^{17}$, Tahir Jalaluddin (1869-1956) was one of the earliest persons who distributed the idea of Islamic reformism in Southeast Asia as well as Indonesia. Born in Bukit Tinggi, West Sumatra in 1869, he went to Mecca in 1881 to pursue advanced education in Islam. After 12 years of study, he moved to Cairo to study Islamic Astronomy at al-Azhar University. It was during this period that he familiarized himself with the thinking of Muhammad 'Abduh, studied with him and was acquainted with his disciple; Rashid Ridha. When Tahir Jalaluddin returned to Mecca for a

\footnotetext{
11 Aviva Schussman, "The Legitimacy and Nature of Mawid Al-Nabī: (Analysis of a Fatwā )," Islamic Law and Society 5, 2 (2016): pp. 214-34.

12 Azyumardi Azra, The Origins of Islamic Reformism in Southeast Asia (Australia: Allen \& Unwin, 2004).

13 Jajat Burhanuddin, "Aspiring for Islamic Reforms: Southeast Asian Requests for Fatwas in al-Manar," Islamic Law and Society 12, 1 (2005): pp. 9-26.

14 William Roff, The Origins of Malay Nationalism (New Haven and London: Yale University Press, 1967).

15 Azyumardi Azra, “The Transmission of Al-Manar's Reformism to the MalayIndonesian World: The Cases of al-Imam and al-Munir," Studia Islamika 6, 3 (1999): pp. 75-100.

16 Burhanuddin, "Aspiring for Islamic Reforms: Southeast Asian Requests for Fatwas in al-Manar."

17 Hafiz Zakariya, "Islamic Reform in Malaya: The Contribution of Shaykh Tahir Jalaluddin," Intellectual Discourse 13, 1 (2005): pp. 49-72.
} 
teaching position, he kept his connection with Ridha by contributing articles in early editions of the journal of al-manar (the lighthouse). ${ }^{18}$

After Tahir Jalaluddin returned to Southeast Asia in 1899, he stayed permanently in Malaya in 1906. His connection with Rashid Ridha had given him religious authority and was therefore able to introduce Islamic reformism in Southeast Asia. Furthermore, he contested the authority of several 'ulamä' who belonged to the Shafi'i madhhab by criticising several practices of the local people he believed were against the Qur'ān and the hadith. ${ }^{19}$ To support his work and activism, Tahir Jalaluddin published a journal of al-Imam (the leader) (1906-1908) that emulated the content of al-Manar.20 For this journal, he invited his students whom he taught in Mecca to be the al-Imam's correspondents in West Sumatra: Abdullah Ahmad (1878-1933), Djamil Jambek (1862-1947) and Abdul Karim Amrullah (Haji Rasul) (1879-1945). It is probable that this relation between Tahir Jalaluddin and his three students contributed to the spreading of Islamic reformism in West Sumatra. As stated by Hamka ${ }^{21}$, Tahir Jalaluddin corresponded regularly with these three students by mails and through publication of al-Imam. This connection inspired Tahir Jalaluddin's students to publish their own journal entitled al-Munir (the radiant) (1911-1915). ${ }^{22}$

Two earliest writing on the mawlid criticisim that was circulated in Southeast Asia and Indonesia was published in the journal al-Manar dan al-Imam. The first publication of mawlid criticism in Southeast Asia appeared in January 1906 when al-Manar answered a question as to the recitation of the mawlid book of al-Dabi. Al-Manar replied to his question by saying that the mawlid book of al-Dabi' contained many

\footnotetext{
18 Azra, "The Transmission of Al-Manar's Reformism to the Malay-Indonesian World: The Cases of al-Imam and al-Munir," p. 83.

19 Zakariya, "Islamic Reform in Malaya: The Contribution of Shaykh Tahir Jalaluddin," p. 52.

20 Roff, The Origins of Malay Nationalism, 59; Jajat Burhanuddin, "Islamic Knowledge, Authority, and Political Power: The "Ulama in Colonial Indonesia" (Leiden University, 2007), p. 180; Azra, "The Transmission of Al-Manar's Reformism to the MalayIndonesian World: The Cases of al-Imam and al-Munir," p. 82.

21 Hamka, Ajabku: Riwajat Hidup Dr. H. Abd. Karim Amrullah Dan Perdjuangan Kaum Agama Di Sumatera (Jakarta: Widjaya, 1958), p. 77.

22 Ibid., p. 77.
} 
false stories, for instance; concerning the creation of the light of Prophet Muhammad which was created by God before Adam. ${ }^{23}$

The second publication of the mawlid criticism was issued in Tahir Jalaluddin's journal of al-Imam in November 1906. The questioner (mustafti) was his own disciple in West Sumatra, Abdullah Ahmad. In that journal, he asked about the ruling of the practice of qiyam in the mawlid celebration according the Islamic law. Concerning this question, al-Imam answered that the practice of qiyam was not authentic because there was no hadith mentioned nor was it practised by the early Muslim generations. ${ }^{24}$

These two journals seem to be the beginning of the struggle of the reformist youth group (kaum muda) against the elderly group (kaum tua) of the followers of the Shafici madhhab on many religious discourses including the mawlid celebration. These publications (and other following printings and journals on Islamic reformism) had given a chance to the reformist to contest the authenticity of the opinion of the kaum tua in the interpretation and the discourse of Islam in Indonesia. ${ }^{25}$ This contestation can be seen in the debates in the following years in West Sumatra regarding some religious issues between kaum tua and kaum muda, including on the qiyam. The first public discussion was held in Padang, West Sumatra in 1907 between two of them on the issue of standing up in the mawlid. On that occasion, the reformists used the rationale of al-Imam to defend their position against this practice. ${ }^{26}$

The writing that can be claimed to be the first criticism to the mawlid celebration that was published in Indonesia (Dutch East Indies) was written by Haji Rasul in 1909 with the title Irshäd al-'awam pada menyatakan maulud nabi alaibi al-salam (the guide for the common people concerning the celebration of the Prophet). It was and an explanation on the proper way of celebrating the Prophet's birthday.

23 Al-Manar, “Al-Manar," 8 (January 1906), pp. 910-11; Nico Kaptein, “The Berdiri Mawlid Issue among Indonesian Muslims in the Period from circa 1875 to 1930," Bijdragen Tot de Taal-, Land- En Volkenkunde 149, 1 (1993): pp. 124-53.

24 Al-Manar, "Al-Manar," 9, April 1906, p. 150; Kaptein, "The Berdiri Mawlid Issue among Indonesian Muslims in the Period from circa 1875 to 1930," p. 134.

25 Jajat Burhanuddin, "Islamic Knowledge, Authority, and Political Power: The 'Ulama in Colonial Indonesia" (Ph.D Thesis, Leiden University, 2007).

26 Kaptein, "The Berdiri Mawlid Issue among Indonesian Muslims in the Period from circa 1875 to $1930, "$ p. 134. 
This book was compiled with several other writings of Haji Rasul and published in 1914 under the title Kitab Lima Risalah (the Book of Five Treatises). ${ }^{27}$ The second book was published in 1913 by Haji Rasul with the title of Iqaz al-niyām fi mā btudi'a min amr al-qiyam (the awakening of the sleeping: dealing with the matter of standing up, which has been innovated). In his statement, Haji Rasul mentioned that in deciding the ruling of qiyam, it is important to focus on the foundational sources (Qur'ān and hadith) rather than blindly follow the saying of the scholars. ${ }^{28}$

Analyzing the above publications of the mawlid's criticisms in the early of $20^{\text {th }}$ century Indonesia, it is interesting to see that the debate between kaum muda and kaum tua in Padang was only about the practice of qiyam in the mawlid celebration. It means that from the beginning, the reformists in Padang did not refuse the notion of the mawlid celebration itself. They only disapproved some practices in the celebration which they considered to be against the Qur'ān and hadith. In fact, Haji Rasul, who wrote several books and articles challenging the practice of standing up, kept reciting the book of mawlid of barzanji but without practicing qiyam. ${ }^{29}$

\section{Muhammadiyah's Opinion on the Mawlid Celebration in the $20^{\text {th }}$ Century}

The religious stance of Muhammadiyah with regard to the mawlid in the $20^{\text {th }}$ century was the same with the opinion of Kaum Muda in the West Sumatra. This can be seen in the journal of Suara Muhammadiyah in 1921. In that edition, which was written in Javanese, Suara Muhammadiyah wrote an article that permitted the mawlid celebration as long as it was in good intention and aimed to make Muslims more pious. ${ }^{30}$

This stance was supported in the Suara Muhammadiyah in 1928. In its question and answer column (kolom tanya jawab), it was written that someone namely Slamet sent a letter with questions concerning

\footnotetext{
27 Abdul Karim Amrullah, Kitab Lima Risalab (Padang: Singkalang, 1914).

28 Abdul Karim Amrullah, Iqaz Al-Niyàm Fi Mā Btudía Min Amr al-Qiyàm (Padang, 1913).

29 Hamka, Ajabku: Riwajat Hidup Dr. H. Abd. Karim Amrullah Dan Perdjuangan Kaum Agama Di Sumatera, p. 70.

30 Suara Muhammadiyah, "Perengetan Woelan Moeloed (Robióelawal) Gatoekipoen Kalijan Mijosing K.N. Moehammad (S.A.W)," Suara Mubammadiyah (Yogyakarta, 1921).
} 
religious issues, two of which related to the ruling of reading the book of mawlid of barzanji and the praising of the Prophet (shalawat) outside the prayer time. The editor of Suara Muhammadiyah replied the two questions as follows:

"Reciting barzanji is allowed, but if it is regarded as religious ritual it will be considered innovation because the Prophet never recited anything other than the Qur'ān. About shalawat, it is permissible to read it. However, anyone who read shalawat must bear in mind that he must not forget to fulfil his religious obligation (such as five times daily prayer). Otherwise shalawat is forbidden". ${ }^{31}$

The above evidence clearly implies that the reformists in Yogyakarta did not object to the mawlid celebration. They allowed the celebration, including reciting barzanji. This opinion is certainly the same with the reformists in Padang who approved mawlid and barzanji recitation. They only disapproved qiyam and did not believe that the Prophet was present in the celebration. Even though Suara Muhammadiyah did not mention their notions on qiyam and the presence of the Prophet, it is plausible that their views were the same with the reformists in Padang.

How come that the opinion of reformists in Yogyarkarta were in line with their colleagues in Padang? Haji Karim Amrullah or mostly known as Hamka explained this in his biography about his father, Haji Rasul. Hamka stated that Haji Rasul visited Ahmad Dahlan (18681923), the founder of Muhammadiyah, in 1917 in Yogyakarta. At that time, it turned out that Ahmad Dahlan was a regular subscriber to the Journal of al-Munir in which Haji Rasul was a regular contributor. When Haji Rasul went back to Padang, he expressed his admiration for the work of Ahmad Dahlan and Muhammadiyah. ${ }^{32}$ In 1925, Haji Rasul joined Muhammadiyah and initiated the founding of Muhammadiyah's branch in Padang. ${ }^{33}$ The description of Hamka shows that both Ahmad Dahlan and Haji Rasul were maintained mutual relationship toward one another. The former was the subscriber to al-Munir and read the work of Haji Rasul, and the latter

31 Suara Muhammadiyah, “Tanya Jawab Agama," Suara Muhammadiyah, 1928, pp. 44042.

32 Hamka, Ajabku: Riwajat Hidup Dr. H. Abd. Karim Amrullah Dan Perdjuangan Kaum Agama Di Sumatera, 1958.

33 Ibid., p. 151. 
was inspired by Muhammadiyah that was founded by Ahmad Dahlan. To this degree, it is not surprising that the reformists in Yogyakarta had the same opinion with the reformists in Padang in relation to the mawlid celebration.

After 1928, I did not find other specific article discussing the mawlid celebration in Suara Muhammad. The only criticism that I find is the one from the reformist organization of Muhammadiyah that was issued in Suara Muhammadiyah in 1987. The criticism was resulted from a question raised by a reader of the magazine. He asked for a clarification from an article that was published in Suara Muhammadiyah stating that Mawlid books such as Barzanji and Diba i contained false information.

To answer this question, Suara Muhammadiyah cited the book of Hasyim Asy'ari in which described the ruling of the mawlid celebration. The magazine said that based on the book, mawlid was allowed by reading the history of the Prophet and by giving almsgiving to the people. However, it emphasized that mawlid was not allowed if the celebration used musical instruments, mixing men and women and the use of loud voices. As to the books of mawlid, Suara Muhammadiyah gave his opinion in the following manner:

"In the mawlid book of al-Diba'i, there are some statements that need to be scrutinised, for instance: the Quraysh (the tribe of the Prophet Muhammad) was the light that was created by the God 2000 years before the creation of Adam. And before Adam was created from clay, God firstly put the Quraysh's light inside that clay. In addition to that statement, there were more accounts that against the religious tenets". ${ }^{34}$

In overall, the statement did not give a prohibition to the mawlid celebration. By citing the work of Hasyim Asy'ari, Suara Muhammadiyah tried to say that the celebration was allowed as long as shunning the use of musical instruments, loud voices and the mixing between men and women. However, it did not hint at another instrument that was allowed by Hasyim Asy'ari; the tambourine (rebana). Regarding the recitation of mawlid books, the 1987's statement was different from the position of Suara Muhammadiyah in 1928 that stated mawlid books were allowed to read. Even though the former did

34 Suara Muhammadiyah, Tanya Jawab Agama (Yogyakarta: Suaraya Muhammadiyah, 1992), pp. 147-50. 
not give its disproval on the recitation, but by saying that mawlid books comprised negative information implied disagreement to the use of mawlid books.

In this respect, Muhammadiyah in 1987 changed its opinion pertaining to the book of mawlid. Muhammadiyah still allowed the mawlid celebration, yet it did not suggest nor to condemn the use of books of mawlid in the celebration of the Prophet's birthday. It only said that the book of mawlid need to be examined related to some information written in those books. The reason why Muhammadiyah shifted its opinion is probably related to the change of the objective of the organization that started in 1937 in which Muhammadiyah put more emphasis on the purification of religious belief, especially when the chairman was held by KH. Mas Mansur (1896-1942) in 1937.35 While in 1928, Muhammadiyah was still concern on the education and it was culturally influenced by the Javanese kingdom of Yogyakarta at which the first chairman of Muhammadiyah worked as royal staff in religious affairs (abdi dalem pamethaken). It is possible that this affiliation made them tolerant to some Javanese traditions that were intermixing with Islam. This tolerant attitude is evident in the Muhammadiyah's stance toward the celebration of the Prophet's birthday of the kingdom of Yogyakarta under the name of gerebeg maulud. This festival is commemorated annually during the whole month of $\mathrm{R} a i^{-}$al-Awwal in Yogyakarta and is celebrated by thousands of people. The Muhammadiyah considered this celebration a cultural expression and withheld its criticism. ${ }^{36}$

Besides that, it must be noted that in terms of its religious stream Muhammadiyah has shifted since its establishment in 1912. From 1912 to 1971 , Muhammadiyah is known for practising the Shafi' 1 madhhab. It can be seen for instance in the Suara Muhammadiyah in 1928 in which the magazine answered a question regarding the madhhab of Muhammadiyah. Replying the question, Suara Muhammadiyah stated that the organization followed the teaching of Shafi' 1 madhhab. ${ }^{37}$ In

35 Ahmad Najib Burhani, "Revealing the Neglected Missions: Some Comments on the Javanese Elements of Muhammadiyah Reformism," Studi Islamika 12, 1 (2005): pp. $101-30$.

36 Herman Beck, "Islamic Purity at Odds with Javanese Identity: The Muhammadiyah and the Celebration of the Garebeg Maulud Ritual in Yogyakarta," in Pluralism and Identity: Studies in Ritual Behaviour, ed. Jan G and Karel Van Der Toorn Platvoet (Leiden: Brill, 1995).

37 Suara Muhammadiyah, “Tanya Jawab Agama,” 1928, pp. 440-42. 
that edition, we can also find a statement of Muhammadiyah allowing the recitation of the mawlid books. This fatwa is in line with the common practice of other Shafi' 1 followers in Indonesia who practice the mawlid celebration.

However, the position of Muhammadiyah related to the Shafi' madhbab is gradually shifted. One cause is due to the influence of $\mathrm{KH}$. Mas Mansur who brought Muhammadiyah into more puritan position by establishing Majelis Tarjih in 1927. The formation of this institute drove Muhammadiyah into more puritan and conservative organization by focusing more of its decisions based on religious principles. We can see this for instance in the national conference of Majelis Tarjih in 1972 in Pekalongan, Central Java, where Muhammadiyah left out many practices that are performed by Shafi' followers. One of them is the qunut supplication in the dawn prayer. Majelis Tarjih Muhammadiyah argues that there are no authentic proofs for conducting such supplication, therefore, the conference decided to dismiss the ritual. ${ }^{38}$ Before that national conference, Muhammadiyah in its prayer guidelines instructed its followers to use the qunüt supplication in the dawn prayer as it prescribed by Shafi' madhbab. ${ }^{39}$ In this regard, the 1972 Majelis Tarjih conference can be marked as the time when the Muhammadiyah is not again part of the Shafi' 'i madhbab. Afterwards, there are other decisions of Muhammadiyah to drop religious practices that belonged to the followers of Shafi'i madhhab, such as the prayer guidelines and the dhikr after prayers. ${ }^{40}$ When Muhammadiyah shifted its position regarding the Shafi' 1 madhbab in 1972, it influenced the stand of Muhammadiyah on the recitation of the mawlid books. As I stated earlier, in 1987 Muhammadiyah started to question the mawlid book of barzanji by saying the barzanji had a lot of negative content. ${ }^{41}$

\footnotetext{
38 Pimpinan Pusat Muhammadiyah, Himpunan Putusan Tarjih (Yogyakarta: Pimpinan Pusat Muhammadiyah, 1974), pp. 366-69.

39 Boekoe Sekolah Moehammadijah, Toentoenan Solat Miturut Madjelis Tardjih (Yogyakarta: Penerbitan Boekoe Sekolah Moehammadijah, 1937), p. 121.

40 Muhammad Ali Shodiqin, Mubammadiyah Itu NU! Dokumen Fiqih Yang Terlupakan (Jakarta: Noura Books, 2014).

41 Suara Muhammadiyah, Tanya Jawab Agama, 1992, pp. 147-50.
} 


\section{Muhammadiyah's Opinion on the Mawlid Celebration in the $21^{\text {st }}$ Century}

In the $21^{\text {st }}$ century, Muhammadiyah criticism on mawlid was published in Suara Muhammadiyah in 2003. In that journal, there was someone sent his inquiries related to three matters: first, on the view of Suara Muhammadiyah about the recitation of shalawat and the book of mawlid of barzanji. Second, when is the best time to recite shalawat and third, whether reciting barzanji will be rewarded by God or not?. ${ }^{42}$

On the first question, the magazine replies by describing that shalawat is a blessing of God to the believers and Suara Muhammadiyah recommends its readers to use the authentic shalawat which is mentioned in the hadith. In addition to that, the magazine indicates that in the recent times there are variations of shalawat recitation that are different from the authentic practice. Examples of these new variations can be found in the book of mawlid of barzanji. ${ }^{43}$

On the second question, Suara Muhammadiyah elucidates that the best time to recite shalawat, for instance, is in the early morning and on Fridays. With regards to the recitation of the mawlid book of barzanji, Suara Muhammadiyah recommends that the reader abandons this practice altogether. Suara Muhammadiyah emphasizes "that the book contains deviated narratives which poison Muslims' faith." The magazine provides an example from the book barzanji: the conception of the light of Prophet Muhammad which was created by God before He created other creatures. Suara Mubammadiyah states that this idea is misleading because it is not based on authentic sources. It says that honouring the Prophet by exaggerating his position is not a sound attitude. ${ }^{44}$

However, according to Suara Muhammadiyah, in recent time there are some shalawat recitations that are different from the authentic practice. Some of them are exaggerating the position of the Prophet and others deviate the principle of Islam. Examples of these two characteristics can be found in the book of mawlid of barzanji. On the question number two, Suara Muhammadiyah elucidates when is the

\footnotetext{
42 Suara Muhammadiyah, Fatwa-Fatwa Tarjib: Tanya Jawab Agama, ed. Muarif (Yogyakarta: Suara Muhammadiyah, 2012), p. 144.

43 Ibid., p. 145

44 Ibid., p. 145
} 
best time to reciting shalawat, for instance, in the morning time and on Friday.

Concerning the recitation of the mawlid book of barzanji, Suara Muhammadiyah recommends the reader not to read it. Suara Muhammadiyah emphasizes that the book contains deviated words and poisons Muslim's faith. The journal provides some examples of the words in the book barzanji: for instance, on the notion of the light of Muhammad which was created by God before other creatures. Suara Muhammadiyah states that this idea is misleading because it is not based on the authentic sources. It says that honoring the Prophet by exaggerating his position is not a good attitude. ${ }^{45}$

Furthermore, the journal mentions a habit that is practised by people who read the book of barzanji. It says that in the middle of the recitation, the participants are suggested to stand up picturing the present of the Prophet among them. Suara Muhammadiyah claims that this practice is a great innovation which is not based on the Qur'ān and hadith. It accentuates that during his life, the Prophet forbade his companions to honour him by standing up when he was coming. ${ }^{46}$

Besides that, there is another writing published in the website of Majlis Tariih Muhammadiyah concerning the question from someone named Untung Sutrino on the issue of the celebration of the Prophet's birthday. He utters that in his community, some people argue that the celebration is lawful and others are not. Thus, he asks the Majlis Tarjib to explain about this matter. ${ }^{47}$

In replying that question, the Majlis Tarjih describes that the fatwo team has received the same question for several times in which the answer has been published in Suara Muhammadiyah. However, the board is willing to explicate it once again. In its explanation, the fatwa team argues that there is no legal basis on the mawlid nor to prohibit people to celebrate it. Therefore, this practice is categorized as a debatable issue (perkara ijtihadiyah) which means that people are not obliged nor forbidden to practice the celebration. If people think mawlid is needed to be celebrated then it is fine. Nonetheless, they have to careful in mixing it with forbidden conducts that are not approved

\footnotetext{
45 Ibid., p. 147

46 Ibid., p. 149

47 Majlis Tarjih Muhammadiyah, 'Peringatan Mawlid Nabi SAW', 2009 http://www.fatwatarjih.com/2011/09/peringatan-mawlid-nabi-muhammad-saw.html (accessed on December 22, 2018).
} 
by our religion; innovated acts that include idolatry by venerating the Prophet and reciting dhikr that have no legal basis in the Qur'ān and hadith. ${ }^{48}$

Analysing the opinion of Muhammadiyah in the $21^{\text {st }}$ century, we can see that there is a continuation and also a shift compared to the view of the Muhammadiyah in the $20^{\text {th }}$ century. The continuation can be seen in the statement of Majelis Tarjih in 2009 that argues that people in certain areas may celebrate the mawlid if they think it is necessary, but noted that it must be in accordance with Islamic law. This is the same with the opinion of Muhammadiyah in the $20^{\text {th }}$ century that stated the mawlid celebration is permissible with the condition that the celebration complies with the rules of Islamic law. Seeing both statements, we can argue that all of them are substantially the same.

In terms of the shift, it is related to the opinion of Muhammadiyah on the recitation of the book of mawlid. In the $20^{\text {th }}$ century, Muhammadiyah did not give a firm recommendation to leave out the recitation of the mawlid book. This is contrary to the recommendation of Muhammadiyah in the $21^{\text {st }}$ century that urge its followers not to read the book of mawlid because it contains deviated narratives and it is poisonous to Muslims' faith. This shift is probably influenced by the social and political condition in the post-Soeharto era in which many Islamic groups tend to be more 'conservative' in the sense that they supported a literal understanding of Islam and rejected any progressive ideas. ${ }^{49}$ He argues that this 'conservative turn' started in 2005 when Indonesian Council of Islamic Scholars (Majelis Ulama Indonesia, MUI) issued a fatwa declaring secularism, pluralism and religious liberalism is contradictory with Islam. ${ }^{50}$ Nur Ichwan contends that in the postSoeharto era, the MUI has "shifted towards more puritanical and strictly literalist interpretation of the faith". ${ }^{51}$ An example in this shift

\footnotetext{
48 Ibid.

49 Martin Van Bruinessen, Contemporary Developments in Indonesian Islam: Explaining the "Conservative Turn" (Institute of Southeast Asian Studies, 2013).

50 Piers Gillespie, "Current Issues in Indonesian Islam: Analysing the 2005 Council of Indonesian Ulama Fatwa No. 7 Opposing Pluralism, Liberalism and Secularism," Journal of Islamic Studies 18, no. 2 (2007): pp. 202-40; Van Bruinessen, Contemporary Developments in Indonesian Islam, p. 16.

51 Nur Ichwan, "Ulama, State and Politics: MUI after Suharto," Islamic Law and Society no. 12 (2005): pp. 45-72.
} 
is the fatwo $\bar{a}$ on Ahmadiyah, inter-religious marriage, inter-religious prayer and inter-religious inheritance.

Moreover, this conservative turn also occurred in Muhammadiyah. As is observed by Najib Burhani, the rise of conservatism in this organization was noted from 2000 to 2010. Burhani based his research on four national congresses of Muhammadiyah (1995 in Aceh, 2000 in Jakarta, 2005 in Malang and 2010 in Yogyakarta). ${ }^{52}$ During these congresses, there were competitions between the progressive and the conservative group within the organization. In the 2005 congress in Malang, the conservative side won "the battle" by getting more votes and electing many of its figures in the national board of Muhammadiyah. The progressive figures like Amin Abdullah (b. 1953) and Abdul Munir Mulkhan (b. 1964) did not get enough ballots and therefore, they did not serve as the national board in that period. The congress also excluded the women's representative on the national board and electing Adian Husaini (b.1965), a conservative figure from a Salafi organization (DDII) to be one of the national board members of the Majelis Tabligh of Mubammadiyah (Council of Religious Propagation).

The conflict between the conservative and progressive groups in Muhammadiyah continued in 2010, with the progressive group was successful to take over the leadership. However, as is stated by Burhani, there was a dilemma among the members of Muhammadiyah due to the conservative - progressive conflict. Several of its members joined more radical groups, such as Hizb ut-Tahrir Indonesia (HTI), the Islamic Defender Front (FPI), the Indonesian Mujahidin Council (MMI), and the Laskar Jihad (Jihad Troops). All of them argued that they are not accommodated by Muhammadiyah and its programme..$^{53}$

Even though it is not directly related, the internal contestation between the progressive and conservative side within Muhammadiyah from 2000 to 2010 has probably influenced the shift of the discourse of mawlid criticism of Muhammadiyah. Especially seeing that fact that the fatwa of Majelis Tarjih on the mawlid was issued in 2003 and 2009, the years during which the conservatives took over the leadership. The

52 Ahmad Najib Burhani, "Liberal and Conservative Discourses in the Muhammadiyah: The Struggle for the Face of Reformist Islam in Indonesia," Martin Van Bruinessen (ed.), Contemporary Developments in Indonesian Islam: Explaining the “Conservative Turn," (Singapore: ISEAS, 2013), pp. 105-44.

53 Ibid., pp. 136. 
second reason is the external factor in which the genre of publication of mawlid criticism is on the rise. The Salafi's endeavour is quite massive to influence the Muslim community by disseminating as many publications as possible which recently dominated the discourse of mawlid criticism. ${ }^{54}$ With this social and political landscape, it is impossible to deny the fact that such discourse could have a possible effect on the Muhammadiyah. Besides, Muhammadiyah as Muslim reformist organization has followers who nurture the idea of returning to the Qur'ann and hadith which is in the same line with the Salafis. What makes Salafi and Muhammadiyah different is the fact that the Salafis are really strict in implementing their principle of returning to the Qur'ān and hadith. They reject independent reasoning (ijtibad) which is practised by Muhammadiyah. In this matter, Muhammadiyah is less orthodox than Salafis due to the strict interpretation of the Salafis on returning of the Qur'ān and hadith without independent reasoning as it practised by Muhammadiyah.

In some writings published by Muhammadiyah, its representatives stated that Muhammadiyah is not the same as the Salafis especially due to the ijtihad part that is practised through Majelis Tarjih. ${ }^{55}$ However, even though Muhammadiyah does not want to be associated with the Salafis, they still try to maintain their relevance with the broader discussion of Islamic puritanism. This can be seen in the fatwo of

54 In my observation, there were at least more than twenty online and offline publications of the Salafis that discussed the issue of the mawlid celebration. Some of them are Abu Mu'awiyah, Studi Kritis Perayaan Mawlid Nabi (Jakarta: Maktabah Latsariyyah, 2007), Buchari, Mustasyar MWC NU Menggugat Mawlid Nabi (Surabaya: Laa Tasyuk! Press, 2013), Basyaruddin bin Nurdin Shalih Syuhaimin, Membongkar kesesatan: tahlilan, yasinan, ruwahan, tawassul, istighotsah, ziarah, dan mawlid Nabi SAW (Bandung: Mujahid Press, 2007), Abu Muawiah Muhammad Aryan, Siapa Bilang Perayaan Mawlid Nabi Bid'a, (Jakarta: Khazanah Islam, 2010), Abdullah bin Abdul Aziz At-Tuwajiry, Adakah Mawlid Nabi, (Bekasi: Darul Falah, 2011), https://almanhaj.or.id/2586-peringatan-mawlid-nabi-menurut-syariat-islam.html. On the Salafi movement in Indonesia see among others: Noorhaidi Hasan, "Laskar Jihad: Islam, Militancy and the Quest for Identity in Post-New Order Indonesia" (Ph.D Thesis, Utrecht University, 2005); Din Wahid, "Nurturing the Salafi Manhaj: A Study of Salafi Pesantrens in Contemporary Indonesia" (Ph.D Thesis, Utrecht University, 2014); Jajang Jahroni, "The Political Economy of Knowledge: Shari'ah and Saudi Scholarship in Indonesia," Journal of Indonesian Islam 7, 1 (2013): pp. 165-186.

55 Suara Muhammadiyah, "Yunahar Ilyas: Muhammadiyah Bukan Kelompok Salaf!," 2016, <http://www.suaramuhammadiyah.id/2016/02/23/yunahar-ilyas-muhammadiyah-bukan-kelompok-salaf/> [accessed on 22 December 2018]. 
Majelis Tarjih of Muhammadiyah on the mawlid in the $21^{\text {st }}$ century which is becoming more conservative compared to Muhammadiyah's decision in the $20^{\text {th }}$ century. By the issuance of the fatwa for banning the use of mawlid book of barzanji, Muhammadiyah wants to be seen as an Islamic group who is upholding the values of Islamic puritanism.

\section{Conclusion}

This article has observed several recommendations of Muhammadiyah pertaining to the mawlid celebration that were published in the journal of Suara Muhammadiyah and its online version. This article strived to answer the following question: what is the Muhammadiyah's opinion on the mawlid celebration in the $20^{\text {th }}$ century and how this discourse changes in the $21^{\text {st }}$ century?

In general, the mawlid criticism was issued firstly in Indonesia by the reformists who introduced the notion of Islamic reform in the early of $20^{\text {th }}$ century. Haji Rasul was the first scholar who published a book on mawlid criticism in 1909. His criticism of the mawlid is mostly related to the practice of qiyam and the belief that the Prophet is present in the celebration. Other than those two, the reformist considered the mawlid tolerable including the custom of reciting the book of mawlid.

The position of Haji Rasul, in general, is the same as the position of the reformist organization of Muhammadiyah. The position of Muhammadiyah regarding the mawlid celebration in the $20^{\text {th }}$ century can be seen in the magazine of Suara Muhammadiyah in 1921 and 1928 , both of which stated that the mawlid celebration is allowed to be practiced. The later edition discussed specifically the recitation of the mawlid book of barzanji. In that publication, Muhammadiyah stated that people are allowed to recite the mawlid book. However, this opinion slightly changed in 1987 by stating that mawlid book of barzanjicontained negative information. In addition to that, Muhammadiyah in this period include some criticisms that were not covered before, such as the use of music and the recitation of barzanji.

In the $21^{\text {st }}$ century, Muhammadiyah's opinion on the mawlid has a similarity and a change with reference to the religious standing of the Muhammadiyah in the $20^{\text {th }}$ century. In 2009 Muhammadiyah argued that people in certain areas may celebrate the mawlid if they think it is necessary, but noted that it must be in accordance with Islamic law. This is the same with the opinion of Muhammadiyah in the $20^{\text {th }}$ 
century that stated the mawlid celebration is permissible with the condition that the celebration complies with the rules of Islamic law. Regarding the change, it is related to the recommendation of Muhammadiyah in 2003 that stated its followers urge its followers not to read the book of mawlid because it contains deviated narratives and it is poisonous to Muslims' faith.

The change of the position of Muhammadiyah regarding the mawlid celebration can be explained through Talal Asad's framework of discursive tradition. As stated by Asad orthodoxy is not static but contingent. It is related to the power relation in which Muslims have the authority "to regulate, uphold, require, or adjust correct practices." This is what happened with Muhammadiyah. Its correct belief related to the mawlid celebration is changing overtime. In 1921 and 1928, Suara Muhammadiyah declares that the mawlid celebration and the recitation of the mawlid book of barzanji is allowed. However, Muhammadiyah shifted its position related to the mawlid book recitation in 1987. This transformation happens due to some dynamics within the organization. In its first establishment, Muhammadiyah was culturally influenced by the Javanese kingdom of Jogjakarta that regularly practiced the annual celebration of gerebeg maulud which was not criticized by Muhammadiyah. Therefore, it is understandable that Muhammadiyah did not denounce the mawlid ritual that was commonly practiced by Muslims in Java.

However, in the years after that, there were some dynamics and changes within the organization. This change is related to the establishment of Majelis Tarjih in 1927 and the role of KH. Mas Mansur as the chairman of Muhammadiyah from 1936 to 1942. This can be seen, for instance, in the shift of the religious stream of Muhammadiyah in 1972 when Majlis Tarjih of Muhammadiyah decided to leave out the teaching and rituals of Shafi'̄ madhhab. Thus, it is not surprising that there was a slight modification of the position of Muhammadiyah in the recitation of the mawlid book of barzanji in 1987 in which the organization highly suspicious with the book by stating that barzanji has deviated. Yet, at that time, Muhammadiyah did not give a firm statement to completely reject the practice of reciting barzanji. The exact recommendation of the Muhammadiyah related to the recitation of the mawlid book of barzanji only occurred in 2003, by stating that its followers must leave out the recitation. Understandably, as the influence of the Salafi discourse in the mawlid criticism is high in 
the post-2000 era, and the conservative faction in Muhammadiyah is in charge, it is highly probable that Muhammadiyah standing is influenced by the position of the Salafi in the mawlid celebration.

The changing of Muhammadiyah standing toward the recitation of the mawlid books of barzanji in the 21 century is another example of Talal Asad's framework of discursive tradition in which the network of power of the Salafis is successful in shaping the opinion of the Muhammadiyah on the mawlid celebration. Before the Salafi's influence, Muhammadiyah in 1987 is neither allows nor prohibits the mawlid recitation. However, after some Salafi figures included in Muhammadiyah in the post-2000 era, they changed its decision, especially in 2003 when Muhammadiyah forbid its followers to recite the mawlid book of barzanji. []

\section{References}

Ali Shodiqin, Muhammad. Mubammadiyah Itu NU! Dokumen Fiqih Yang Terlupakan. Jakarta: Noura Books, 2014.

Al-Manar. “Al-Manar.” 8, January 1906. “"Al-Manar." 9, April 1906.

Amrullah, Abdul Karim. Iqaz Al-Niyàm Fi Mà Btudi'a Min Amr alQiyàm. Padang: n.p., 1913.

Kitab Lima Risalah. Padang: Singkalang, 1914.

Asad, Talal. "The Idea of an Anthropology of Islam." Washington D.C.: n.p., 1986.

Azra, Azyumardi. The Origins of Islamic Reformism in Southeast Asia. Australia: Allen \& Unwin, 2004.

-------. “The Transmission of Al-Manar's Reformism to the MalayIndonesian World: The Cases of al-Imam and al-Munir." Studia Islamika 6, 3 (1999): 75-100.

Beck, Herman. "Islamic Purity at Odds with Javanese Identity: The Muhammadiyah and the Celebration of the Garebeg Maulud Ritual in Yogyakarta." Jan G and Karel Van Der Toorn Platvoet (eds). Pluralism and Identity: Studies in Ritual Behaviour. Leiden: Brill, 1995. 
Boekoe Sekolah Moehammadijah. Toentoenan Solat Miturut Madjelis Tardjih. Yogyakarta: Penerbitan Boekoe Sekolah Moehammadijah, 1937.

Burhani, Ahmad Najib. "Liberal and Conservative Discourses in the Muhammadiyah: The Struggle for the Face of Reformist Islam in Indonesia". Martin Van Bruinessen (ed.). Contemporary Developments in Indonesian Islam: Explaining the 'Conservative Turn'. Singapore: Institute of Southeast Asian Studies, 2013.

---------. "Revealing the Neglected Missions : Some Comments on the Javanese Elements of Muhammadiyah Reformism". Studi Islamika 12, 1 (2005): 101-30.

Burhanuddin, Jajat. "Aspiring for Islamic Reforms: Southeast Asian

Requests for Fatwas in al-Manar". Islamic Law and Society 12, no. 1 (2005): 9-26.

-------. "Islamic Knowledge, Authority, and Political Power: The 'Ulama in Colonial Indonesia". Ph.D Thesis, Leiden University, 2007.

--------. "Islamic Knowledge, Authority, and Political Power: The 'Ulama in Colonial Indonesia”. Leiden: Leiden University, 2007.

Delong-bas, Natana J. Wabhabi Islam: From Revival and Reform to Global Jihad. London: Oxford University Press, 2004.

Gillespie, Piers. "Current Issues in Indonesian Islam: Analysing the 2005 Council of Indonesian Ulama Fatwa No. 7 Opposing Pluralism, Liberalism and Secularism." Journal of Islamic Studies 18, 2 (2007): pp. 202-240.

Hamka. Ajabku: Riwajat Hidup Dr. H. Abd. Karim Amrullah Dan Perdjuangan Kaum Agama Di Sumatera. Jakarta: Widjaya, 1958.

Hasan, Noorhaidi. "Laskar Jihad: Islam, Militancy and the Quest for Identity in Post-New Order Indonesia”. Ph.D Thesis, Utrecht University, 2005.

Hurgronje, C. Snouck. Mekka in the Latter Part of the 19th Century. Leiden: Brill, 2007.

Ichwan, Nur. "Ulama, State and Politics: MUI after Suharto". Islamic Law and Society 12 (2005). 
Jahroni, Jajang. "The Political Economy of Knowledge: Shari'ah and Saudi Scholarship in Indonesia". Journal of Indonesian Islam 7, 1 (2013): pp. 165-186.

Kaptein, Nico. "Materials for the History of the Prophet Muhammad's Birthday Celebration in Mecca". Der Islam 2, 69 (1992): pp. 193203.

Muhammad's Birthday Festival: Early History in the Central Muslim Lands and Developement in the Muslim West until the 10th/16 Century. Leiden: EJ. Brill, 1993.

-. "The Berdiri Mawlid Issue among Indonesian Muslims in the Period from circa 1875 to 1930.” Bijdragen Tot de Taal-, Land- En Volkenkunde 149, 1 (1993): 124-153.

Katz, Marion Holmes. The Birth of the Prophet Muhammad; Devotional Piety in Sunni Islam. London and New York: Routledge, 2007.

Pimpinan Pusat Muhammadiyah. Himpunan Putusan Tarjih. Yogyakarta: Pimpinan Pusat Muhammadiyah, 1974.

Roff, William. The Origins of Malay Nationalism. New Haven and London: Yale University Press, 1967.

Schussman, Aviva. "The Legitimacy and Nature of Mawid Al-Nabī: (Analysis of a Fatwāa)". Islamic Law and Society 5, 2 (2016): pp. 214-34.

Suara Muhammadiyah. Fatwa-Fatwa Tarjih: Tanya Jawab Agama. Edited by Muarif. Yogyakarta: Suara Muhammadiyah, 2012.

--------. "Perengetan Woelan Moeloed (Robióelawal) Gatoekipoen Kalijan Mijosing K.N. Moehammad (S.A.W).” Suara Muhammadiyah. Yogyakarta, 1921.

--------. Tanya Jawab Agama. Yogyakarta: Suara Muhammadiyah, 1928.

-. Tanya Jawab Agama. Yogyakarta: Suara Muhammadiyah, 1992.

Van Bruinessen, Martin. Contemporary Developments in Indonesian Islam: Explaining the "Conservative Turn. Singapore: ISEAS, 2013.

Voice of Muslim, Buku-Buku Penerbit Wabhabi Laa Tasyuk Dan TemaTema Basi, 2014. http://www.muslimedianews.com/ 2014/04/buku-buku-penerbit-wahhabi-laa-tasyuk.html. 
Wahid, Din. "Nurturing the Salafi Manhaj: A Study of Salafi Pesantrens in Contemporary Indonesia." Ph.D Thesis, Utrecht University, 2014.

Zakariya, Hafiz. "Islamic Reform in Malaya: The Contribution of Shaykh Tahir Jalaluddin." Intellectual Discourse 13, 1 (2005): pp. 49-72.

\section{Internet Sources}

Suara Muhammadiyah, "Yunahar Ilyas: Muhammadiyah Bukan Kelompok Salaf!", 2016 <http://www.suaramuhammadiyah.id/2016/02/23/yunahar-ilyas-muhammadiyah-bukankelompok-salaf/> [accessed on 22 December 2018].

Majlis Tarjih Muhammadiyah, 'Peringatan Mawlid Nabi SAW', 2009 <http://www.fatwatarjih.com/2011/09/peringatan-mawlidnabi-muhammad-saw.html $>$ [accessed on 22 December 2018]. 